\title{
Bibliometric and Trend Analysis of Budget Transparency
}

http://doi.org/10.21272/bel.4(2).116-122.2020

Molotok Ihor Fedorovych, ORCID: https://orcid.org/0000-0002-7392-6416

Sumy State University, Sumy, Ukraine

\begin{abstract}
Over the last few decades, an integral part of public finance development is budget (fiscal) transparency and accountability. It is also in the focus of scientific interest and international organizations' activity. Nevertheless, there is still a lack of valuable empirical research on identifying key triggers and inhibitors of budget (fiscal) transparency and its cohesion with other concepts in public finance management. Thus, this research deals with the realization of several tasks: 1) identification of budget (fiscal) transparency genesis and its essence in modern terms; 2 ) clarification of its cohesion with other concepts in public finance management using modern tools of bibliometric analysis; 3 ) characteristics of a current state of budget transparency in Ukraine, identification problems and prospects in this sphere. The second task fulfillment is based on Google Ngram Viewer, Google Trends and VOSviewer bibliometric tools. Implementation of Google Ngram Viewer is aimed at popularity quantification of the concepts "budget transparency", "fiscal transparency" and "budget accountability" in English Google books for 1960-2012. It defines budget (fiscal) transparency and accountability became the focus of scientific interest starting from 1960th, demonstrating an increase from the 1990th, and peaked in 2005. Google Trends analysis also showed that the peak of Internet users' interest in budget (fiscal) transparency issues was in 2005-2006. Moreover, Google Trends analysis and frequency of Scopus articles published on the budget (fiscal) transparency issues lead to the conclusion that this concept remains popular among both scientists and regular Internet users worldwide. VOSviewer analysis of 419 Scopus articles reveals that budget (fiscal) transparency closely connected with economic prosperity and sustainability at national and local levels, poverty elimination, environmental responsibility, democratic values implementation, fight against corruption, good governance, and especially the efficiency of public finance management, fiscal policy and government expenditures. Finally, analysis of budget transparency level in Ukraine based on Open Budget Survey 2019 allows concluding that despite the general improvement of the country score (from 54 to 63 points) in comparison with the previous Survey period, Ukraine still has problems with Mid-Year Review and Pre-Budget Statement.
\end{abstract}

Keywords: Bibliometric Analysis, Budget Accountability, Budget Transparency, Google Ngram, Google Trends, Fiscal Transparency, VOSviewer.

JEL Classification: E62, H30, O23.

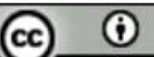

Cite as: Molotok, I.F. (2020). Bibliometric and Trend Analysis of Budget Transparency. Business Ethics and Leadership, 4(2), 116-122. http://doi.org/10.21272/bel.4(2).116-122.2020.

(C) The Author, 2020. This article is published with open access at Sumy State University.

\section{Introduction}

Over the last few decades, the development of public finance at national and local levels associates with numerous qualitative changes and reforms. Global challenges and peculiarities of a particular country's development cause such transformations. Specifically, the necessity of an increase of budget resources allocation efficiency leads to the implementation of transparency and accountability as core principles of budget process organization. These two issues become important because budget (fiscal) transparency and accountability allow local citizens to deal with budget resources redistribution, underline government priorities, find out the strengths and weaknesses of budget planning and budget process. Moreover, the provision of international financial aid is impossible without budget transparency and accountability. Besides, numerous empirical researches state that good governance in public finance based on transparent and accountable background helps to gain better economic and social performance. Consequently, these principles become an integral part of public finance management in developed countries and actively implemented in developing countries. 
Considering the importance of budget transparency principle at the current stage of public finance development, it becomes necessary to fulfill several urgent tasks at empirical and theoretical levels:

1. Identification of budget (fiscal) transparency genesis and its essence in modern terms;

2. Clarification of its cohesion with other concepts in public finance management using advanced tools of bibliometric analysis;

3. Characteristics of a current state of budget transparency in Ukraine, identification problems and prospects in this sphere in our country.

\section{Literature Review}

One should note that primary recommendations regarding country budget transparency were developed in 1999 by International Monetary Fund in its Code of Good Practices on Transparency in Monetary and Financial Policies (IMF, 1999). In 2007 it was developed in the Code of Good Practices on Fiscal Transparency (IMF, 2007) and in 2019 updated in The Fiscal Transparency Code (IMF, 2019). In this document (IMF, 2019), fiscal transparency is identified as "comprehensiveness, clarity, reliability, timeliness, and relevance of public reporting on the past, present, and future state of public finances". It covers four pillars such as fiscal reporting, fiscal forecasting and budgeting, fiscal risk analysis and management, and resource revenue management (IMF, 2019) that underline certain recommendations on how to raise fiscal transparency in the above perspectives of public finance management. Namely, in terms of fiscal reporting, IMF recommends providing comprehensive, clear, high-quality reports by all public sector subjects on regular base.

Moreover, fiscal reports might be built on statistical data allowing international and historical comparativeness. Fiscal forecasting and budgeting recommendations aimed at building of public finance management on comprehensive, timely, and credible background. Besides, central and sub-central governments need to realize fiscal risk analysis and management to timely identify potential damages for public finance system and mitigate these risks. Recommendations regarding the resource revenue management deal with openness and accountability in terms of collecting and redistribution of revenues from natural resource exploration and extraction activity (IMF, 2019). It should be noted that each of four pillars consists of principles, which have to be clarified as basic, good or advanced. It is worth noting that the Organisation for Economic Co-operation and Development also actively involves in budget transparency worldwide dissemination. Specifically, in 1999 OECD Working Party of Senior Budget Officials also developed some recommendations, which form a background for the OECD Best Practices for Budget Transparency (OECD, 2002) and further developed in OECD Budget Transparency Toolkit (OECD, 2017).

All the international organizations create their recommendations on budget (fiscal) transparency separately, but they cooperate as well in this sphere. Based on the result of the standard-bearer's collaboration in this sphere, the establishment of the Global Initiative for Fiscal Transparency (GIFT) was initiated in 2011. The World Bank, the International Monetary Fund, the International Budget Partnership (IBP), the Organisation for Economic Co-operation and Development, and the Departments/Secretaries of the budget of Brazil and the Philippines' governments were actively involved in GIFT establishment (OECD, 2017). GIFT was created to disseminate budget (fiscal) transparency on a supranational-based level and ensure unity and collaboration between countries in this perspective. In 2016 GIFT developed 10 Principles of Public Participation in Fiscal Policy (GIFT, 2016). These are accessibility, openness, inclusiveness, respect for self-expansion, timeliness, depth, proportionality, sustainability, complementarity, and reciprocity of public finance management. These GIFT Principles nowadays lead the system of internationally developed recommendations on budget (fiscal) transparency and good governance.

Moreover, the International Budget Partnership (IBP) launched the Open Budget Survey and Open Budget Index that consider nowadays as a unified measure of budget transparency. The index varies from 0 to 100 (IBP, 2020). It should be noted that budget transparency is not only in the focus of international organizations, but also is widely researched in empirical studies. Specifically, Cimpoeru and Cimpoeru (2015) investigated on how budget transparency (measured with Open Budget Index) influences control of corruption and economic performance (measured with GDP per capita). Using multiple panel data regression analysis, the authors revealed that an increase of the Open Budget Index in a point results in an increase of control of corruption in 0.45 points (at $1 \%$ confidence level).

Based on the analysis of 20 peer-reviewing scientific empirical papers on budget (fiscal) transparency, Stanic (2018) found out several blocks of its determinants: 
$>$ Financial (leverage and debt);

$>$ Political (political competition, executive features and governance type);

$>$ Citizens and the media (population, internet access, unemployment, and the media).

In turn, Birskyte (2018) proposed to construct a budget transparency index for 60 Lithuanian municipalities based on 20 criteria concerning object issue. Data were collected from the municipalities' official web sites. The binary system was used (if the municipality fulfills the criterion then 1 , elsewise -0 ) to assess budget transparency. The next stage of the research was aimed at clarification of crucial determinants of subnational governments' budget transparency. The author empirically proved that Lithuanian municipalities' budget transparency depends on borrowing, revenue per person, level of intergovernmental grants, percentage of the population living in rural areas, size and age of the population, and political activism.

Sedmihradská and Jakub (2012) explore how budget transparency might influence public expenditures. The research revealed that an increase in budget transparency leads to more effective and rationale budget resources distribution. In turn, authors also found out that a decrease in information asymmetry might improve fiscal accountability and stimulate more effective fiscal rule fulfillment. The popularity of the budget (fiscal) transparency at the supranational level demonstrates that there is still a limited amount of valuable empirical researches on the identification of key triggers and inhibitors of it and its cohesion with other concepts in public finance management. Thus, it becomes an urgent and useful task to realize more in-depth and comprehensive research on this issue.

\section{Methodology and Results}

First, it should be noted that this goal would be realized using bibliometric analysis tools such as Google Ngram Viewer, Google Trends and VOSviewer. Analytical results of Google Ngram Viewer aimed at quantification of popularity in English Google books such concepts as "budget transparency", "fiscal transparency" and "budget accountability" for 1960-2012 (the last available data) are presented in Figure 1.

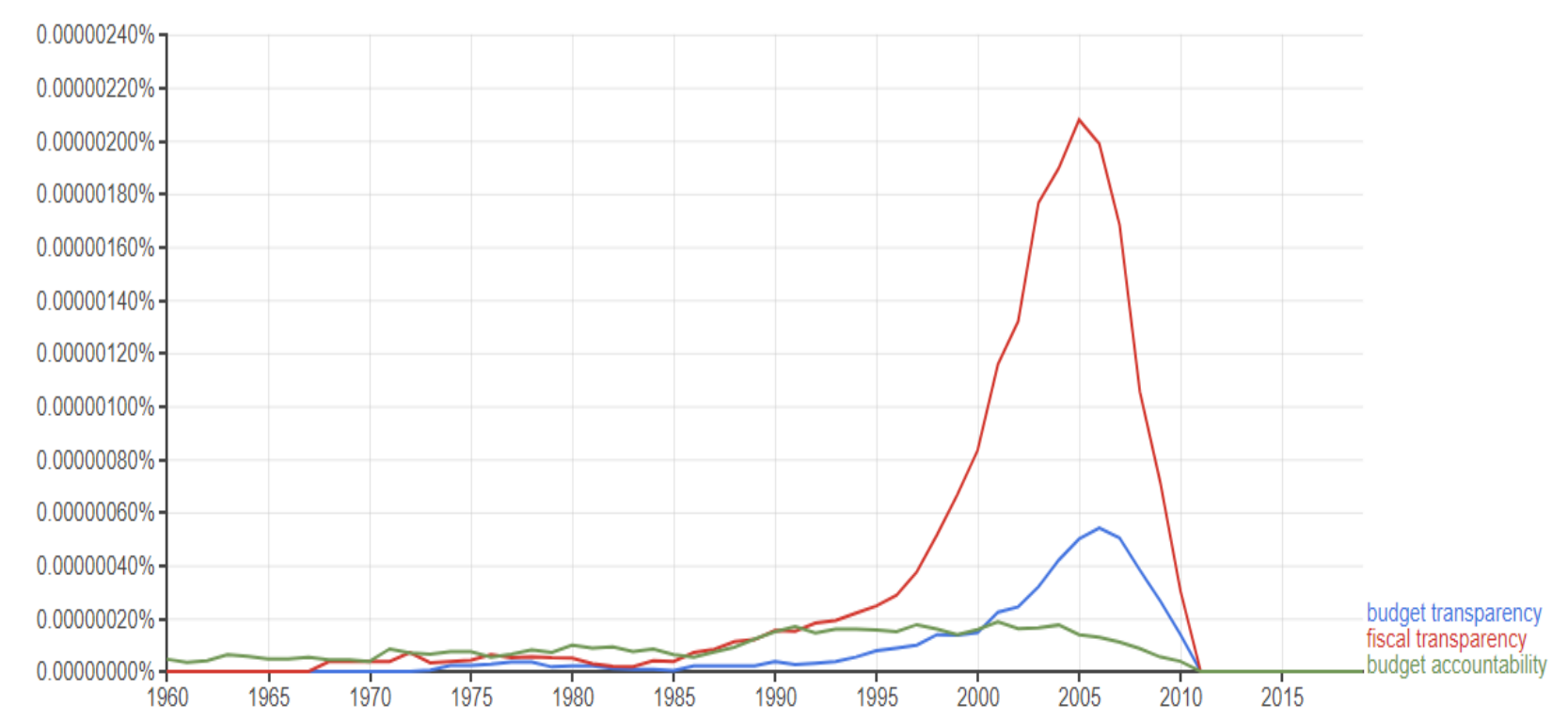

Figure 1. Results of Google Ngram Viewer for 1960-2012

Source: Google Books Ngram Viewer, 2020

Based on the analytical information from Figure 1, we can conclude that emerging ideas on budget / fiscal transparency and budget accountability was in 1960. The popularity of these issues varied insignificantly in 1960-1985. From the early 1990th questions concerning fiscal transparency and budget accountability became more popular that resulted in the development of IMF and OECD recommendations on budget/fiscal transparency during the late 1990th. Fiscal transparency issues peaked in popularity in Google books in 2005. Almost the same trend was highlighted for budget transparency, while scientific interest to budget accountability problems remained stable in 1990-2005 but went considerably down after 2005. Loss of scientific interest to the above concepts after 2005 might be explained by the widespread implementation of these principles and their clarification at the supranational level. Thus, the scientific focus might be switched 
from theoretical aspects of the problem to its empirical study. Using Google Trends instruments, we can analyze the frequency of Internet users' requests on the mentioned topic. Thus, Figure 2 characterizes the dynamics of users' requests concerning "budget transparency" worldwide in 2004-2020.

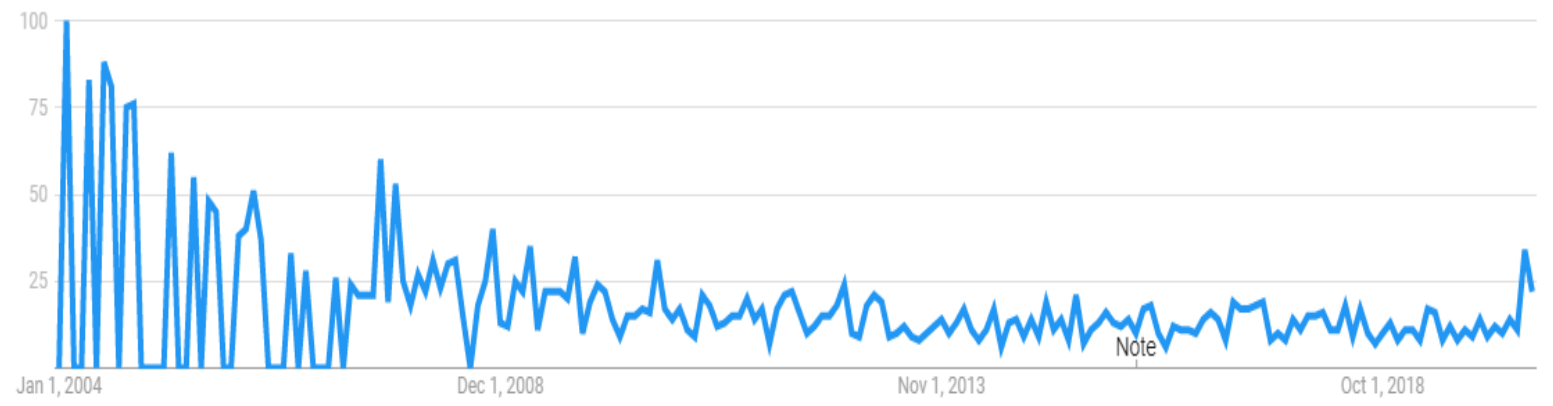

Figure 2. Results of Google Trends of Internet users requests about "budget transparency" worldwide in 2004-2020

Source: Google Trends, 2020

Thus, analysis of the data presented in Figure 2 allows concluding that the peak of Internet users' interest in the problem of budget transparency was in 2005-2006 that is familiar to Google Ngram Viewer results. It should be noted that this graph presents not just the amount but scale of the Internet users' requests: the maximum number of the requests during the analyzed period got 100 points while the points for the rest of the observations were calculated compared to the maximum value. However, Google Ngram Viewer observations period ended in 2012, Google Trends covers by far new data. Specifically, it might be noted that in 2012-2020 Internet users' request intensity concerning budget transparency remain stable, but it was about eight times less than in 2005-2006. These results prove that budget transparency issues remain rather popular but not a key topic. While analyzing 2012-2020, we can find out that the peak of Internet users' interest in this problem was in September 2012.

The next stage of the research is aimed at clarification cohesions of "budget transparency" with other concepts using VOSviewer (Figure 3). Thus, VOSviewer analysis based on the 419 Scopus articles, which are focused on the budget transparency issues allow us to get five clusters such as: 1) cluster 1 (focused on macroeconomic perspectives and consequences of budget transparency): budget; budget control; decentralization; economics; environmental impact; fiscal rules; government; local government; local participation; policy making; sustainability; sustainable development; water quality; 2) cluster 2 (focused on fiscal transparency and fiscal policy issues): budget deficit; economic growth; expenditures; financial system; fiscal policy; fiscal transparency; political budget cycles; political economy; poverty alleviation; public administration; public spending; strategical approach; 3 ) cluster 3 (focused on specifically budget transparency and accountability, and good governance): accountability; budget transparency; civil society; economic development; finance; governance; governance approach; 4) cluster 4 (transparency and democracy focus): budgeting; democracy; open government; public sector; transparency; 5) cluster 5 (corruption and rule of law focus): corruption; management; public procurement. 


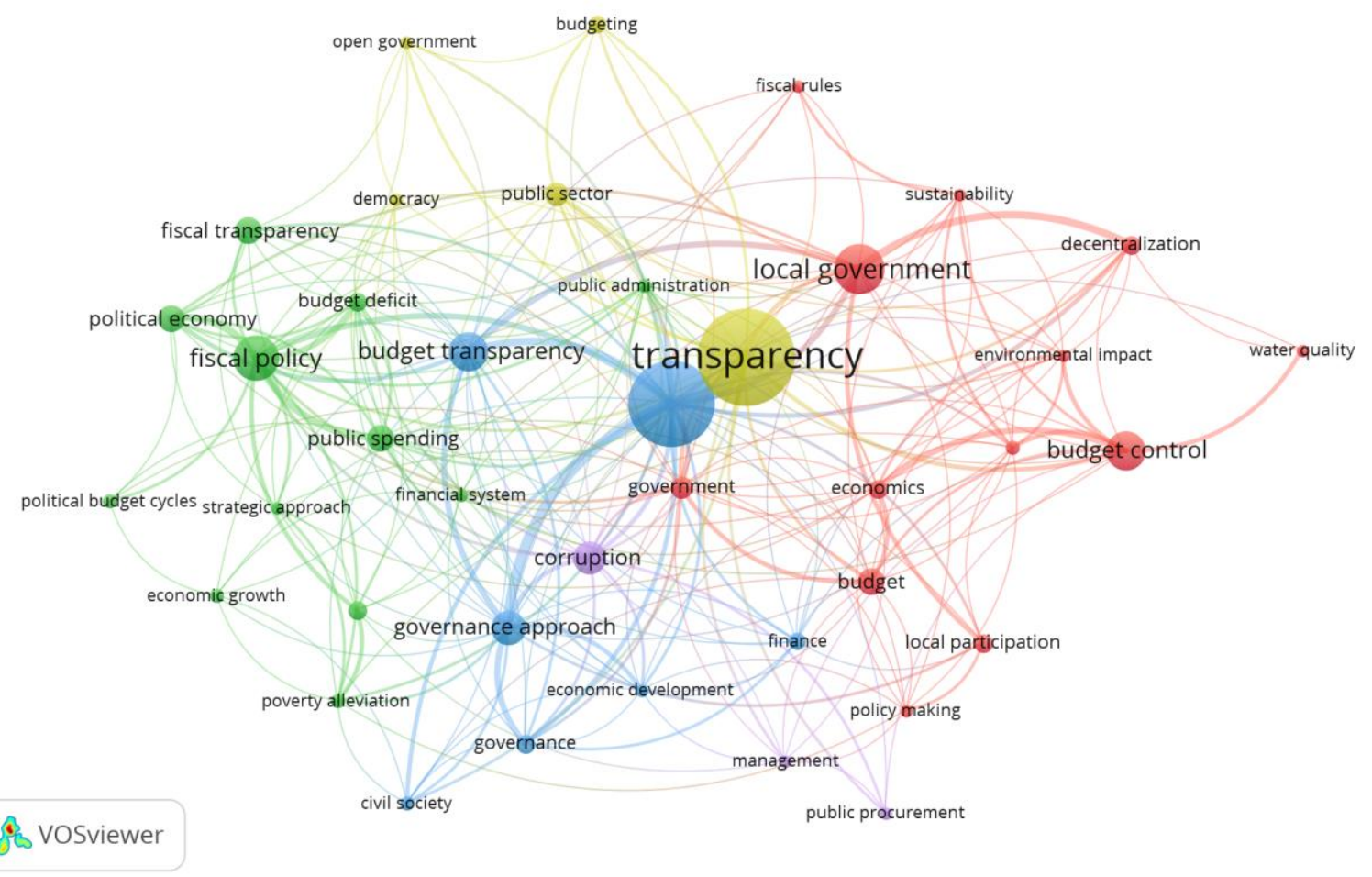

Figure 3. Results of VOSviewer analysis on cohesion of budget transparency with other concepts based on Scopus articles for 1992-2020

Source: VOSviewer, 2020

Research results revealed that budget transparency closely connected with economic prosperity and sustainability at national and local levels, poverty elimination, environmental responsibility, democratic values implementation, fight against corruption, good governance, and especially the efficiency of public finance management, fiscal policy and government expenditures. In turn, Figure 4 allows us to analyze the dynamics of changes of scientific interest to the topic.

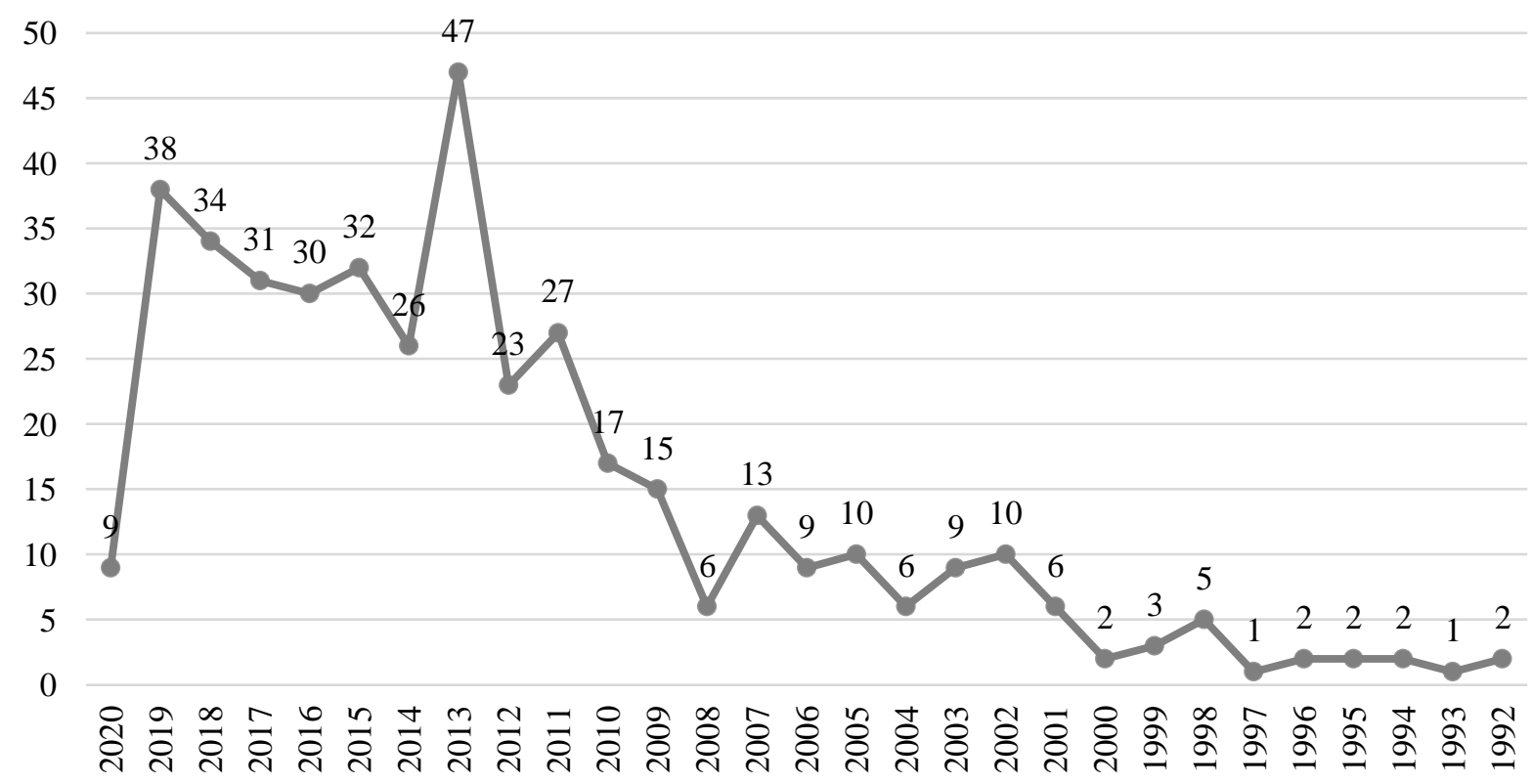

Figure 4. The dynamic of published Scopus articles for 1992-2020 concerning budget transparency, amount of articles

Source: Scopus, 2020

The analytical information from Figure 4, shows that scientific interest to the problem of budget (fiscal) transparency was rather insignificant in 1992-2000, but in 2001-2008 its popularity among scientists slightly 
increased. 2009-2013 might be characterized as a period of significant growth dynamic that allows the reach of a peak of scientific interest: 47 Scopus articles were published on budget transparency issues in 2013 that might be correlated with the introduction of Open Budget Survey and Open Budget Index. Nevertheless, during 2014-2019 budget transparency issues remained rather popular scientific direction that supports the idea about its theoretical, practical and scientific relevance. After analysis of the theoretical background of budget transparency genesis and its cohesion with other concepts in public management, it is useful to analyze Ukraine's current states, problems and prospects in this sphere based on the Open Budget Survey (International Budget Partnership, 2020).

Ukraine's position in the ranking of budget transparency based on the Open Budget Survey 2019 is in Figure 5. Based on the information from the Open Budget Survey 2019, we can conclude that Ukraine has a sufficient level of budget transparency and has 26 positions out of 117 countries. In comparison with the Open Budget Survey 2017, the score of Ukraine raised on 9 points that allows moving from insufficient to sufficient budget transparency level. Moreover, it has better performance than the global average and slightly better performance than most of our Western neighbors. Nevertheless, Ukraine has 9 points lower score than Russia.

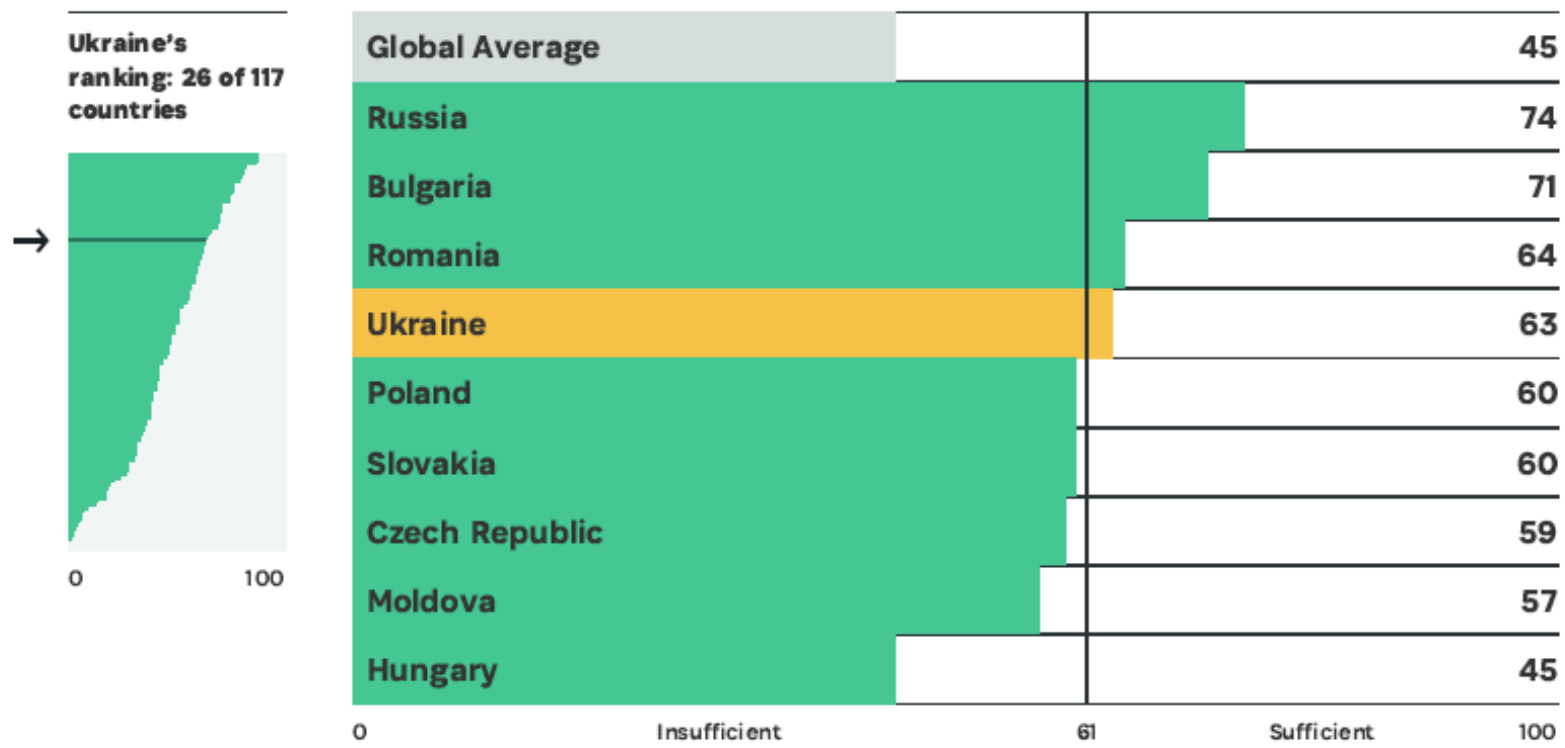

Figure 5. Position of Ukraine in budget transparency ranking based on the Open Budget Survey 2019 (International Budget Partnership, 2020)

Source: International Budget Partnership, 2020

The in-depth analysis of the Open Budget Survey 2019 allows us to underline that in terms of budget transparency ensuring our country is quite successful (61-100 points) in such perspectives as Executive's Budget Proposal, Enacted Budget, Citizens Budget, In-Year Reports (the highest score - 93 out of 100), YearEnd Report and Audit Report. In turn, the Pre-Budget Statement got 45 scores (average cluster), while the Mid-Year Review not produced in our country at all (International Budget Partnership, 2020). However, there are two key directions for budget transparency improvement in Ukraine. First, there is a necessity of Mid-Year Review implementation aimed at reporting after the middle of the fiscal year, updating key performance indicators, and adjusting budget revenue and expenditure considering macroeconomic indicators. Secondly, it is also necessary to be more transparent in Pre-Budget Statement development and publication so that citizens can understand the macroeconomic and monetary background for state and local budget plans. According to the Open Budget Survey 2019 (International Budget Partnership, 2020), in terms of Pre-Budget Statement improvement Ukraine should provide "additional information on revenue policies and priorities for the upcoming budget year; estimates related to government borrowing and debt; and multi-year expenditure projections."

\section{Conclusions, Discussion and Recommendations}

Thus, based on the theoretical and analytical analysis, it can be concluded that budget (fiscal) transparency and accountability became in the focus of scientific interest starting from the 1960th, it began to increase from the 1990th and reached a peak in 2005. In turn, first drafts of international recommendations on budget (fiscal) transparency were developed by the International Monetary Fund and the Organisation for Economic Cooperation and Development only at late 1990th, while an international initiative aimed at budget (fiscal) 
transparency dissemination - Global Initiative for Fiscal Transparency (GIFT) - was created in 2011. Moreover, Google Trends analysis and frequency of Scopus articles published on the budget (fiscal) transparency issues lead to the conclusion that this concept remains very popular among both scientists and regular Internet users. In turn, VOSviewer analysis of 419 Scopus articles revealed that budget transparency closely connected with economic prosperity and sustainability at national and local levels, poverty elimination, environmental responsibility, democratic values implementation, fight against corruption, good governance, and especially the efficiency of public finance management, fiscal policy and government expenditures. An analysis of Ukraine's profile in the Open Budget Survey 2019 (International Budget Partnership, 2020) allows the summary that budget transparency in our country has become better than that of 2017, resulting in 9 points increase in the country's total score. This improvement allows Ukraine to move to a sufficient budget transparency group. Nevertheless, despite the positive trend in the strengthening of budget transparency in 2019, there are still some problems in this sphere concerning Pre-Budget Statement and Mid-Year Review. It is proposed to implement Mid-Year Review and make Pre-Budget Statement development more comprehensive, holistic and oriented on real macroeconomic situations to solve existing problems in budget transparency in Ukraine.

\section{References}

1. Alt, J. E.; Lasen, D. D. (2006). Fiscal transparency, political parties, and debt in OECD countries. European Economic Review, 50(6), 1403-1439. https://doi.org/10.1016/j.euroecorev.2005.04.001.

2. Birskyte, L. (2018). Determinants of Budget Transparency in Lithuanian Municipalities. Public Performance \& Management Review, 42(3), 707-731. DOI: 10.1080/15309576.2018.1507915.

3. Cimpoeru, M. V.; Cimpoeru, V. (2015). Budgetary Transparency - an Improving Factor for Corruption Control and Economic Performance. Procedia Economics and Finance, 27, 579-586. https://doi.org/10.1016/S2212-5671(15)01036-9.

4. Dener, C.; Min, S. Y. (2013). Financial Management Information Systems and Open Budget Data: Do Governments Report on Where the Money Goes? Washington, DC. World Bank. https://doi.org/10.1596/978-1-4648-0083-2.

5. GIFT (2016). Principles of Public Participation in Fiscal Policy. Retrieved from: http://www.fiscaltransparency.net/pp_principles/.

6. Google Books Ngram Viewer (2020). Retrieved from: https://books.google.com/ngrams.

7. Google Trends (2020). from: https://trends.google.com/trends/explore?date=all \&q=budget $\% 20$ transparency.

8. International Budget Partnership (2020). Open Budget Survey. Retrieved from: https://www.internationalbudget.org/open-budget-survey.

9. International Monetary Fund (1999). Code of Good Practices on Transparency in Monetary and Financial Policies. Retrieved from https://www.imf.org/external $/ \mathrm{np} / \mathrm{mae} / \mathrm{mft} /$ code/index.htm.

10.International Monetary Fund (2007). Code of Good Practices on Fiscal Transparency. Retrieved from: https://www.imf.org/external/np/fad/trans/code.htm.

11.International Monetary Fund (2019). The Fiscal Transparency Code. Retrieved from: https://www.imf.org/external/np/fad/trans/Code2019.pdf.

12.Jarmuzek, M. (2006). Does Fiscal Transparency Matter? The Evidence from Transition Economies. Retrieved from: https://www.cerge-ei.cz/pdf/gdn/rrc/RRCV_77_paper_03.pdf.

13.OECD (2017). OECD Budget Transparency Toolkit: Practical Steps for Supporting Openness, Integrity and Accountability in Public Financial Management, OECD Publishing, Paris. http://dx.doi.org/10.1787/9789264282070-en.

14.OECD (2002). OECD Best Practices for Budget Transparency. Retrieved from: https://www.oecd.org/gov/budgeting/best-practices-budget-transparency.htm.

15.PEFA (2020). The Public Expenditure and Financial Accountability program. Retrieved from: https://www.pefa.org/about.

16.Raipa, A.; Backūnaitè, E. (2004). Fiscal Transparency and Accountability in the Public Management Methodology. Public Policy and Administration, 1(8), 48-57. Retrieved from: https://www3.mruni.eu/ojs/public-policy-and-administration/article/view/2460.

17.Scopus (2020). Retrieved from: https://www.scopus.com/.

18.Sedmihradská, L.; Jakub, H. (2012). Budget transparency and fiscal performance: Do open budgets matter? Retrieved from: https://mpra.ub.uni-muenchen.de/42260/1/MPRA_paper_42260.pdf.

19.Stanic, B. (2018). Determinants of subnational budget/fiscal transparency: a review of empirical evidence.

Public Sector Economics, 42(4), 449-486. https://doi.org/10.3326.pse.42.4.4.

20.VOSviewer (2020). Retrieved from: https://www.vosviewer.com/. 